\title{
War And Reconstruction: Four Comparative Case Studies
}

Pieter Kapp ${ }^{\bullet}$

Traditionally defeated nations or peoples were regarded as at the mercy of the victorious powers. They were either incorporated into the power structure of the dominant power as a vassal or annexed by the victorious state, or were subjected to a humiliating peace treaty that did not provide for full restoration of their sovereignty. Very little attention was given to society at large; they were simply left at the mercy of whoever represented the new power. War as an instrument to reconstruct an entire society as a fully independent and sovereign state based on a new set of principles and an economic system in harmony with that of the triumphant party, is more closely associated with a revolution than with war in the traditional sense of the word. War as a means to create new states either through unification or separation is well known in history. But war to change the hearts and minds of entire society were less known before the twentieth century.

Four wars that in some way or other were aimed at reconstructing a body politic and an entire society by not only changing their political institutions but also ideology and political, social, economic and cultural paradigms, form the subject of this comparative study. It was thus not only a military and political defeat that was involved, but the surrender of an entire way of life, a revolution that was to be forced on the defeated from outside, whatever the views or role of individuals or other groups or organisations in that society might have been. The military were in the front line of not only the war but represented the power of the victorious and had as such to act as the agents for ensuring the successful implementation of the new dispensation. The military had to take charge of a plan or programme for transforming all aspects of public, and even many of private, life. Their role was regarded as agents of fundamental change which would only terminate when a sovereign and hopefully a purified political leadership was ready and able to take over what would hopefully be an entirely re-made society.

The four case studies are taken from four different continents, four different wars under four totally different sets of circumstances. Many arguments can be raised about the validity of the four selections and the comparability of the cases. It could even be argued that any effort at comparison is likely to fail because the differences overshadow any suggestion of significant similarities. The four wars and the resulting reconstruction policies are the following:

- The American Civil War (1861-8165) and the reconstruction of the Confederacy, a period in American history that are indeed known as Reconstruction (1865-1877). This was not a war conducted by two belligerent powers but a civil war involving constitutional and racial issues of great importance to the American system and society.

- The Anglo Boer War (1899-1902) in South Africa, a war of imperial conquest and expansion and sanctified by the idea that it is a war to expand British civilization and progressive political, economic, social and cultural development in southern Africa.

Department of History, University of Stellenbosch. 
- The Second World War in Europe against Germany (1939-1945) to liberate Europe and mankind from Nazi tyranny and to denazify Germany.

- The war against Japan (1941-1945) to liberate the Far East from Japanese domination and aggression and to democratize and reconstruct Japanese society.

In all four cases the military were the vanguards and the safeguards of the new dispensation. It was only through inflicting convincing defeat that the victors could even consider a total reconstruction of society at large. The purpose of this presentation is to examine issues that could be found to be comparable and to develop perspectives on them. Relevant questions that arise are:

- What were the original war aims of the winning powers?

- What role did the military play in formulating both the aims and the post-war policies to achieve those aims?

- What was the relationship between the military and civil authorities of the occupying powers and the domestic leadership emerging after the wars?

- How successful were the reconstruction policies and what role did the military play in its success or failure?

- How did the defeated nations respond to the reconstruction policies?

\section{Can a comparison of these four cases be justified?}

Significant differences between the four cases are obvious. They were four totally different wars, fought for entirely different reasons with vastly different military doctrines and strategies. There would, however, appear to be two common elements in all four: the decision that the defeated peoples should be subjected to a grand design for fundamental reconstruction and that the military might of the victors should be the main instrument for achieving this programme. Although the reconstruction programmes were designed for four completely different nations or societies with different values, customs and cultures, there are a number of common elements represented in them that will be looked at in each case.

Apart from these elements there are a number of related issues that indicate comparable developments.

\subsection{Current actuality}

The integration of the eleven Confederate states into the Union, the problem of states' rights, the heritage of emancipation and the conflicting policies of racial segregation and integration form part and parcel of contemporary American history and society. The current debate in some of the southern states on Southern heritage and identity and Confederate symbols and remembrance confirm this. ${ }^{1}$ The reunification of Germany in 1990, the debate on the deployment of German troops in the Balkans and the desire of the German government to regain an international role commensurate to its status as a leading power in Europe, all reflect on the

See article in Time April 30, 2001 (Ghosts of the South). 
reconstruction policies of the post-war era. The arguments over American military bases in Japan, over Japan's military role, the present Prime Minister's endorsement of new history textbooks against the protests of China and Korea that it does not represent the truth about Japan's role in the war, and the planned visit of the Japanese Prime Minister to the tombs of Japanese war heroes all indicate the sensitivities that still exist. ${ }^{2}$ Japan's refusal to apologise unconditionally for their conduct in the war is a further confirmation that in spite of everything that happened since the occupation, the reconstruction policy is still extremely influential in Japan. The current commemoration of the Anglo Boer War in South Africa has generated great interest and a number of debates on various aspects of the war. With the centenary of the Peace of Vereeniging due next year one can expect new debates on the policy of heropbou (reconstruction) of the two Boer Republics. Interestingly enough the reconstruction and reconciliation policy of the post-1994 government in South Africa has spurned only a limited interest thus far in the reconstruction and reconciliation policy of the British in the two Boer republics.

\subsection{Historical controversy}

In all four cases there are ongoing debates on the meaning, success and significance of the reconstruction period. It is unlikely that the debate will be exhausted in the near future. The reconstruction policies were too involved with local and international politics and were too complex for a single interpretation or perspective to dominate. An entire historiography has developed in each of the four cases. The historiography represents a variety of interpretations between two extremes. On the one extreme those on the left and the right who regard reconstruction as a total failure. The argument on the left is that it did not produce fundamental and revolutionary changes in the structures and power relations in society and only restored the dominating position of the capitalist classes. Conservative interpretations condemned reconstruction as an unwarranted and insensitive imposition on the lives of millions of people who were nothing more than innocent victims of war and it could have had chaotic effects if the original intentions were realised. Fortunately, the argument claims, this was prevented by the timely termination of reconstruction in all four cases. Those who view reconstruction as a great success which secured democracy, stability and economic growth, point out how a new competent and democratic leadership benefited from the newly created democratic institutions and from restored economic growth.

Reconstruction was initially presented very negatively in American historiography. The Traditionalist, often referred to as the Dunning School or the Dunningnites, described the Reconstruction Era as "The Tragic Era", "the Dreadful Decade", "The Age of hate". "The Blackout of honest government" and "the nadir of national disgrace". 3 In their view the good Abraham Lincoln wished to restore the South to the Union with minimum humiliation and maximum speed. But the Radical Republicans in Congress, motivated by hatred of the South, selfish political ambitions and gross economic interests, repudiated Lincoln and Andrew Johnson's conciliatory policies. They put the South under military occupation, enfranchised the ex-slaves and Afro-Americans and instituted corrupt governments in the South controlled by

Time July 9, 2001, p. 28.

For example William A Dunning of Columbia University in a series of monographs; Claude Bowers: The Tragic Era (1929); John W. Burgess: Reconstruction and the Constitution (1901); James G. Randall: Civil War and reconstruction (1937); E Merton Coulter: The South during Reconstruction 1865-1877 (1947); 
carpetbaggers and "scalawags". This view of Reconstruction was unchallenged until the thirties when revisionists, ${ }^{4}$ Afro-American scholars ${ }^{5}$ and Marxists $^{6}$ argued that although there were serious flaws in the Reconstruction administration, the policies were rather lenient towards the South and that the loss of their slaves was about the only direct intervention into the lives of Southerners. While the Civil War is often described as a glorious time of gallantry, an heroic age in the evolution of the American system and the apex of liberty through the abolition of slavery, Reconstruction is viewed as a rather messy period unbecoming the heroism of the war.

The unique situation that developed with the partition of Germany and the establishing of Soviet control in not only East Germany but in East and Central Europe as a whole, tended to divert attention away from the reconstruction policy as such. Denazification and reconstruction became linked to saving the Germans from a communist takeover and this in turn gave rise to the rebuilding of West Germany as a bulwark against Communist expansion and as a model democratic capitalist Western state. Especially Americans often present the recovery of West Germany as the product of benevolent American reconstruction. But denazification proper was something different from the reconstruction of a West German state. It is indeed an open question whether reconstruction would have succeeded if the negative programme of denazification had not been brought to an abrupt end and replaced by the constructive political, economic and military rebuilding of West Germany. Denazification, especially in the American zone, has been seriously criticized by American historians and condemned by German writers. ${ }^{7}$

Similar controversy exists among American scholars on the success and meaning of reconstruction policy in Japan. In contrast to the historiography on the American South, where the initial judgement was very negative and only later replaced by a more balanced view, American historiography on Japan went the other way round. Those in support of Douglas MacArthur's policies and achievements hailed the American policy as fundamental reform, establishing a complete break with the authoritarian past and putting Japan back on the modernisation road that the Meiji began. ${ }^{8}$ Critics, on the other hand, argued that there was no thorough purge of the old authoritarian elements in Japan. The prewar ruling oligarchy should have been replaced by truly democratic and anti-imperialist elements as represented in the trade union movement, peasant associations, universities and moderately left-wing parties. ${ }^{9}$ New Left

$4 \quad$ Howard K. Beale, 'On Rewriting Reconstruction History', American Historical Review XLV, 1940 , pp. 807-827; John Hope Franklin, Reconstruction after the Civil War (1961); James G Randall and David Donald, The Civil War and Reconstruction (1961); C Vann Woodward, Reunion and Reaction: The Compromise of 1877 and the end of Reconstruction (1951).

$5 \quad$ W E B du Bois: Black Reconstruction (1935)

6 James S Allen: Reconstruction: the battle for democracy 1965-1877 (1937).

7 John H Herz, 'The Fiasco of Denazification in Germany', Political Science Quarterly, December 1948; Constantine Fitzgibbon, Denazification (Michael Joseph, London, 1969); John D Montgomery, Forced to be Free. The Artificial Revolution in Germany and Japan (University of Chicago Press, 1957); Rainhold Maier, Ein Grundstein wirdt gelegt. Die Jahre 1945-1947 (Rainer Wunderlich, Tübingen, 1964); Lutz Niethammer, Entnazifisierung in Bayern. Säuberung und Rehabilitierung unter Amerikanischer Besatzung (Fischer, Frankfurt am Main, 1972)

$8 \quad$ Edwin O Reischauer, The United States and Japan (Harvard UP, Cambridge, Mass., 1965); Robert E Ward, Political Development in Modern Japan (Princeton UP, 1968); Herbert Passin, 'Occupation Reforms as Experiments in Guided Social Change' in The Legacy of the Occupation-Japan. Occasional Papers of the East Asian Institute, Columbia University, 1968.

9 Owen Lattimore, Solution in Asia (Little Brown, Boston, 1949); T A Bisson, Prospects for Democracy in Japan (Macmillan, New York, 1949); Miriam Farley, Aspects of Japan's Labor Problem (John Day, New York, 1950). 
historians accused America of deliberately restoring Japan as an economic and political power in Asia and of reintroducing limited rearmament and thus canceling the original aims of a transformation of Japanese society. They emphasize that what American policy did do was to continue the class structure, maintaining the position of the ruling personnel and strenghthening prewar domestic and foreign policies, institutions and attitudes. ${ }^{10}$

Historical controversy on reconstruction after the Anglo Boer War is concentrated on three main issues: the role and policy of Sir Alfred Milner, the British High Commissioner in South Africa and Governor of the Orange River and Transvaal Colonies; the retention of white power and segregation; and the rise of Afrikaner nationalism. The initial studies were, similar to the MacArthur case in Japan, full of praise for Milner and his great work to secure South Africa for the British Empire. ${ }^{11}$ Later studies gave Milner credit for the way in which he tried to reconcile the defeated Boers through promoting economic growth and development but failed to contain Afrikaner or African nationalism ${ }^{12}$. Afrikaner historians, on the other hand, held that Milner failed completely to reconcile Afrikaners to the new dispensation and that his name has since become symbolic of all that is negative in the British Empire and imperialism. ${ }^{13}$ For others Milner's policy is proof of the close link between imperialism and capitalism, for whom the rights and interests of both black and white labour, was of less importance than the promotion of capitalism. ${ }^{14}$ The refusal of Milner to grant black Africans, coloureds and Indians the vote in the Free State and Transvaal, the very limited attention given to their land claims and the fact that race policy was left unchanged, were regarded by others as the worst part of Milner's failed policy. ${ }^{15}$ The unification of South Africa in 1910 was seen as a positive development which spelled the fortunate end to Milner's unsuccessful attempt at creating a truly British South Africa.

\subsection{War aims}

John W Dower, Empire and Aftermath: Yoshida Shigeru and the Japanese Experience, 1878-1954 (Harvard UP, Cambridge Mass., 1979); William Borden, The Pacific Alliance: United States Foreign Economic Policy and Japanese Trade Recovery, 1947-1955 (University of Wisconsin Press, Madison, 1983); Joe Moore, Japanese Workers and the Struggle for Power, 1945-1947 (University of Wisconsin Press, Madison, 1983); Michael Schaller, The American Occupation of Japan and the Origins of the Cold War in Asia ( Oxford UP, New York, 1985).

J. Buchan, The African Colony (London, 1903); W B Worsfold, The Reconstruction of the New Colonies under Lord Milner, 2 vols (London, 1913).

12 G H L le May, Britsh Supremacy in South Africa, 1899-1907 (Oxford UP, 1965).

13 A P J van Rensburg, 'Die Ekonomiese Herstel van die Afrikaner in die Oranjerivierkolonie, 1902-1907' (Archives Year Book for South African History, 1967 part two); S J Esterhuizen, 'Die ekonomiese rehabilitasiepogings gedurende en onmiddellik na die Tweede Vryheidsoorlog ter opheffing van die Transvaalse burgers' (Unpublished MA thesis, University of Pretoria, 1952); P M B Schutte, 'Die verhouding tussen Boer en Brit in die Transvaal' (Unpublished MA thesis, University of Pretoria 1979); D A van der Bank, 'Die stryd om die behoud van die identiteit van die Afrikaner in die Oranjerivierkolonie, 1902-1910' (Unpublished D Phil, University of the Free State, 1979) period of reconstruction 1900-1905 (Longman, London, 1973). Philip, Cape Town, 1984); P. Warwick, Black People and the South African War, 1899-1902 (Ravan, Johannesburg, 1983) 
The aims of the post-war policies were closely linked to the war aims. In all four cases reconstruction was viewed as not only a golden opportunity to establish democratic, progressive and cooperative governments, but that it also placed a special responsibility on the victors' shoulders to provide moral leadership that would ensure peace and prosperity in the region. Even the Soviet Union described its actions and policies in East Germany in these terms: establishing real democracy that could only be achieved if political power and ownership of the means of production were in the hands of the working class. From the victors' point of view the causes of the wars were different but they had one thing in common: the fundamental errors in values and consequently in the conduct of the defeated nations.

In the case of the American Civil War there is an important distinction between what at the time were perceived as the causes of the war, and what became a popular version. Historians present three perspectives on the causes of the war. Firstly, states' rights versus federal rights, as demonstrated in conflicts over tariffs, over nullification (the right of a state government to restrict the application of a federal law) and over the right of secession. By 1860 the threat of secession was nothing new. Various state governments regularly reverted to this method to emphasize their opposition to federal policy. Secondly, the economic and political differences and competition between North and South. The North was Republican, the South Democratic. The North was a wealthy industrialised and commercial society eager to obtain markets for its manufactures. The South was an agricultural society based on a planter economy with large estates, yeomen farmers and slavery. Thirdly, the emancipation of the slaves, which was strongly advocated by reformers and abolitionists who were concentrated in the North. Emancipation was also no new issue. The granting of statehood to each new territory admitted to the Union, led to rousing debates on whether slavery should be allowed in the new state or not. The fact that the emancipation proclamation was eventually signed by Abraham Lincoln at the height of the war in 1863 , tended to make slavery the focal point of the war. Lincoln was not an enthusiastic abolitionist. For him the war was first and foremost about restoring the union. In his proclamation of April 15, 1861 Lincoln called up his troops and the militia to suppress a rebellion, not to fight a war. Strangely enough the captured Confederate soldiers were not treated as traitors but as prisoners of war. During the first year of the war Lincoln refused to interfere with slavery and he gave no sign that he would make its abolition a condition of reconstruction. That Lincoln was a reluctant emancipator is proved by his message to Congress in December 1862, in which he once again proposed that each slave state develop its own plan of gradual, compensated emancipation, which need to be completed before January 1900. The emancipation proclamation of January 1, 1863 applied only to those areas in the South still in rebellion. Complete and unqualified emancipation did not come through actions of the President but by the Congress adopting Amendment X111 in 1865.

It was only after Lincoln signed the Emancipation Proclamation that emancipation became a decisive issue in the war. The American Congress, however, was deeply divided on the issue and the Radical Republicans saw the war as a war to liberate the slaves and they therefore insisted on a programme of radical reconstruction after the war. Historians and the general public accept nowadays that although states' rights were the technical cause of the war, the real issue was slavery. If the abolition of slavery were the real cause of the war, the treatment of slaves after the war could be expected to be central to reconstruction policy.

The causes of the Anglo Boer War are also a heavily disputed matter. Britain's claim that the war was forced upon her by the treatment Her Majesty's subjects were receiving in the 
South African Republic - especially on the granting of the vote and the awarding of contracts was rejected by Kruger's government. Historians point out that it was control of the gold mines, British expansion and the need to prevent European competitors from gaining a foothold in southern Africa, which caused the war. Britain was the aggressor; the republics were defending their independence and their right not be imposed upon by British military power and presence. For the South African Republic it was a Freedom War against the second attempt by Great Britain to subjugate it. If British control of the subcontinent was the major aim of the war, the reconstruction policy could be expected to be aimed at achieving precisely that.

The causes of the European and Asian hostilities eliminated the possibility of similar controversies developing on the causes of the Second World War. If Germany and Japan's initial aggression was limited to restoring the pre-Versailles situation or to demonstrating their opposition to the economic stranglehold that America was maintaining against Japan, a controversy might have developed. But the open aggression and territorial and ideological expansionism that marked the war, left no doubt that this war was about conquest and liberation. This left the victors with an open hand as to post-war policy. Unconditional surrender was the natural thing to demand. That would give the victors the opportunity to dictate not only policy but also an entirely new political and socio-economic dispensation that should safeguard the world against the recurrence of such atrocious wars. Japan and Germany must never again be in a position to subject the world to such a catastrophe. The acceptance of guilt for the war should rule out any attempt by the defeated nations to resist reconstruction policies on the argument that they were not responsible for the war and thus did not deserve the treatment meted out to them. The necessity of paying reparations and war debts, and the right to punish severely the leaders and to democratize the defeated nations were generally accepted. How this was to be put into practice was a controversial matter. Proposals ranged from the complete destruction and dismemberment of the existing states, to a controlled revolution and re-education.

Examined comparatively, the situations offer scope for great differences in reconstruction policy. But they had one thing in common: the right of the victors to impose their ideology and their interest and socio-economic systems on the vanquished.

\subsection{Aims of the reconstruction policies}

In a message to a special session of Congress as early as July 4, 1861 Lincoln spelled out his post-war policy: re-establishing unity and reconfirming the validity of the constitution and the federal laws. In his view it was not the task of the government to win a war, but to disperse bands of rebels and establish loyal governments in the South. To restore the constitutional position was the responsibility of the President not of the Congress. As soon as a substantial area of the South was under federal occupation Lincoln began to devise and implement a programme of his own without consulting Congressional leaders or the Congress. On December 8, 1863 he issued a proclamation of amnesty and reconstruction and invited each southern state to take advantage of this opportunity. If $10 \%$ of the voters in a state took the oath of allegiance they could reorganise their state government and return representatives to their seats in Congress.

While the problem of interpreting the boundaries of state authority and federal power was at the basis of the Civil War, reconstruction soon developed into a different constitutional tuck of war, this time between the powers of the President and the Congress. Although the new Republican Party controlled both the White House and Capitol Hill, it could not forestall a 
serious clash on the nature and limits of executive and legislative powers. Prosecution of Southern leaders, a lengthened military occupation of the South and the entire reconstruction of society were not part of Lincoln's post-war aims. Southerners would not be exposed to investigations of their political alliances or their personal activities. Radical Republicans regarded Lincoln's policy as too lenient to the South. Their aim was a radical democratization of the South, extending political and social rights to the ex-slaves and forcing the South to integrate them fully. Military government would be necessary to establish control of affairs and to prevent any political subversion from taking root. Leaders of the Confederacy should be put on trial as war criminals and a new leadership class should be developed in the South

Post-war policy in Germany became the subject of intense debate as early as 1943 when the Teheran Conference clearly stated the intentions of the Allied powers not to repeat the mistakes of the First World War. Unconditional surrender, prosecution of the guilty, complete removal of the political, military and economic elite, disarmament, demilitarisation, reparations for war damage and debt payment for the military costs of the war effort and the abolition of Germany as a single state (the so-called dismemberment resolution) were the initial aims of the United States, the United Kingdom and the Soviet Union, a clear sign that the Allies intended the war settlement to be a drastic one. ${ }^{16}$ At Yalta the concept of dismemberment was replaced by the idea of a transition period of Allied occupation to be followed by the restoration of German unity. Germany was no longer to be dismembered but to be divided into three occupation zones (later four when France was also accepted as an Allied occupation power). This fundamental change in policy was due to two factors. Firstly, Winston Churchill's insistence that the Allied Powers should not, as was the case after World War 1, carry the responsibility for the financial and economic recovery of Germany. Germany must not again become a burden to its victors. Seecondly, Stalin's support for a policy of undisturbed control of that part of Germany closest to the Soviet Union. Stalin never hesitated to remind his partners that the Soviet Union had very special claims against Germany. The Red Army made the main contribution to the defeat of the Nazi's and the Soviet people suffered the greatest losses and should therefore receive ample compensation from the whole of Germany, not from the Soviet zone only. The formula for Soviet reparations was never settled and became a serious problem in the administration of Germany.

The other post-war aims remained unchanged with ideological cleansing (called denazification) added to the programme. The occupation arrangements were finalised at Potsdam where the first signs of serious difficulties ahead for Allied cooperation already appeared. It was clearly stated that a coherent reconstruction policy was to be followed in the different zones and the responsibility to ensure this was put in the hands of military leaders represented in the Allied Control Council for Germany and the Commandatura for the four zones of Berlin. The Potsdam Agreement clearly stated that occupied Germany should be treated as an economic unit and that the earliest possible economic recovery of Germany should be the aim. A coherent policy soon proved very difficult to achieve. It was the French at first who gave clear indications that they had their own ambitions as far as the future of Germany was concerned: the "lost" French territories of Alsace-Lorraine and the entire area west of the Rhine should be either incorporated into France or reorganised in a way that would meet French interests. The most serious obstacles came from the Soviet Union who acted unilaterally in a number of fundamental changes of policy. A coherent policy collapsed when Marshal Sokolovsky walked out of the Allied Control 
Council in September 1948. Not only was the division of Germany into two states inevitable, but the hope of a peace treaty to finally end the war, also vanished. ${ }^{17}$ When the main aim of Allied control, maintaining a unified Germany, failed, it had serious consequences for the rest of the reconstruction policy. Events would soon prove that the division of Germany entirely changed the nature of reconstruction.

Allied cooperation in occupied Japan was at best a paper construction. Although 11 powers shared the occupation, and were supposed to act as partners in the development of policy, the reconstruction of Japan was totally dominated by the United States. American policy in turn was in the hands of the military commander General Douglas MacArthur. His official designation was Supreme Commander Allied Powers (SCAP) and he was to receive policy directions from the Far Eastern Commission (FEC) of all 11 allied powers in Washington and from the War, State, Navy Coordinating Committee (WSNCC). But by the time of the FEC's first meeting on February 26, 1946 the US had already set broad policy for Japan. The international control of Japan was never a serious problem for MacArthur for it left his authority unhampered. The continuity provided by MacArthur obviated the possibility of major changes in American (or Allied) policy as had happened in the Southern states and in Germany. But MacArthur himself altered course when he announced on March 19, 1947 that reconstruction was complete and that America should withdraw from Japan and initiate peace talks. This change in MacArthur's attitude was not approved by Washington, which was by then deeply concerned about the evolving Cold War. Why then this change in MacArthur's policy? Schonberger explains it in terms of MacArthur's ambition to become the Republican presidential candidate. ${ }^{18}$ His eyes were now on American politics, where it was important for him to be presented as the great and successful reformer of Japan - just the kind of President the United States needed. Schonberger notes the paradox of MacArthur, the hater of Roosevelt, adopting Roosevelt's New Deal policy in Japan. ${ }^{19}$

The aims of the reconstruction policy was clearly spelled out:

- A new democratic constitution based on the American model.

- A purge of the traditional leadership ensuring that neither the Emperor nor the military nor the aristocracy nor the zaibatzu families should have political power.

- Total economic restructuring and the break up of the monopolies controlled by the zaibatzu.

- Complete disarmament and demilitarization.

- Break up of the feudal system through land reform and redistribution of land among the peasants.

- Abolishing the Shinto religion and its hold on Japanese values and society.

- A new education system to develop democratic and international values.

17 M Balfour, 'Four Power control of Germany', Yearbook of International Affairs, 1956 (Oxford UP, 1956).

18 Howard B Schonberger, Aftermath of War. Americans and the Remaking of Japan, 1945-1952, chapter 2 (Kent State UP, 1989) 
In South Africa reconstruction was also dominated by one man, Sir Alfred (later Lord) Milner. ${ }^{20}$ Milner was closely involved in the policies and events that led to war. As British High Commissioner for South Africa it was his continuing pressure on the South African Republic that sabotaged efforts at a negotiated settlement. Milner was convinced that the war would be a blitzkrieg and that it should be aimed at the total breakdown of the Boer morale ${ }^{21}$ while causing as little physical damage as possible. Like MacArthur he was ambitious, egotistical and unwilling to share power. Not being a military officer, he lacked the power base that MacArthur enjoyed. He was against a military government for the two new colonies and was eager to get the British generals out of the way. He realised the need for a military presence but only if it was under his strict control. The South African Constabulary, a "strong semi-military police" fulfilled the role of an occupation force. He prided himself on the fact that "I have saved the British position in South Africa, and I have knocked the bottom out of 'the great Afrikaner nation' for ever and ever. Amen." ${ }^{22}$ His experience of fighting Egyptian nationalism ${ }^{23}$ and the British defeat by the Transvaal in 1881 convinced him that nationality was the most important issue to be dealt with in South Africa. Afrikaner nationalism was obstacle number one to achieving his aims and must be eroded. Anglicisation was the term he and his officials commonly used to describe his policy aims. It referred both to the increase of British numbers and the cultural assimilation of Afrikaners. ${ }^{24}$ Establishing complete British control and securing the subcontinent for the Empire by strengthening British demographic and economic power, could be achieved without the use of military power. Self-government for the two new colonies similar to that enjoyed by the Cape and Natal, could ultimately be installed but only once British control and dominance has been secured. This was to be achieved by means of the following concrete policy programme:

- Large-scale settlement of British immigrants in the Free State and Transvaal. Boundary changes to include part of Transvaal in Natal and land redistribution through agricultural settlements were aspects of the grand design.

- Economic recovery based on the gold mines and satellite industries and on markets created by the mining activities.

- Development of a railway system that could serve the markets, facilitate control of the country and demonstrate the economic interdependence of the four colonies and Rhodesia.

- A thoroughly British civil administration that could control both Afrikaners and the non-white population groups.

- An education system that would encourage British values and imperial ideals, denationalising Afrikaners and reducing the Dutch language to a minor role in an effort to prevent Afrikaner unity.

- Securing loyalty from the republicans by protecting white control.

See the article by E T Stokes, 'Milnerism' The Historical Journal (Canada), 1962.

See the famous, and often disputed, quote by Molteno that Milner claimed "I am determined to break the dominion of Afrikanerdom". J.T. Molteno, The dominion of Afrikanerdom; recollections pleasant and otherwise (London, 1923), p. 184

In a letter to his friend James Rendel, 30 May 1900. Quoted by Donald Denoon, Op cit., p. 59.

He wrote a book on his experience: England and Egypt (London, 1892).

Donald Denoon, op. cit., p. 40. 
- No vindictive policy towards the Bittereinders and the Boer leaders but demanding that they sign an oath of loyalty to the Queen.

The aims of the four reconstruction policies had to deal with a number of corresponding issues:

- Political reconstruction, especially in the form of political rights and new constitutions.

- Economic reconstruction and rebuilding.

- Social and cultural changes, with a strong real or pretended ideological dimension.

- Land reform.

- Military and defence matters.

\section{Reconstruction policy in the American South}

Lincoln's reluctance to introduce any revolutionary changes in the South, apart from the emancipation of the slaves, is clearly represented by his veto of drastic measures proposed by Congress. In the summer of 1862 Congress adopted the Second Confiscation Act that provided for treason to be punished by fines, imprisonment or death. It defined another crime, that of engaging in rebellion or insurrection for which it prescribed severe penalties, including fines, imprisonment or confiscation of property. This would have led to a vast social revolution in the South and the economic liquidation of the old planter aristocracy. Lincoln sabotaged the measures by not enforcing them. He wanted no martyrs at whose shrines Southerners could worship for generations to come. He also knew that the growth of a vigorous Republican Party in the South, would need the support of many ex-confederates. Lincoln did not insist on the vote for blacks. He never abandoned his hope that the great mass of ex-slaves could be persuaded to leave the country. Establishing colonies for them to settle in was one of his ambitions. Colonising efforts in Haiti and Ile á Vache were a catastrophe and Lincoln ended the disgraceful episode by bringing the survivors back.

The Radical Republicans pinned their hope on Andrew Johnson who took over the presidency after the assassination of Lincoln on April 13, 1865. But Johnson soon proved himself independent of the Republicans and more or less continued with the Lincoln policy, which lead to a serious confrontation between him and Congress. The latter even tried to impeach Johnson, an effort that was only narrowly defeated. After the 1866 election the Radical Republicans had a strong enough position in Congress to challenge the executive power with the help of moderate Republicans, and to push their own programme of reconstruction. From December 1865 to the President's impeachment trial in the spring of 1868, Radicals and Johnson engaged in a fascinating dialogue. Much of it was an intensely serious discussion of several fundamental problems: the proper relationship of the legislative and executive branches; the legitimate areas of federal and state responsibility; and the terms that might justly be imposed upon the defeated South. The central issue of the dialogue was the position of the freed slaves in American society. Johnson insisted that the South remain white man's country. The Radicals wanted to throw out the Black Codes, which had been passed by the new loyal state governments and which placed all kinds of restrictions on the exercise of black political actions. They wished to extend civil rights to all Afro-Americans, grant them the ballot, introduce a land redistribution 
policy and provide social and economic aid to the freedmen. In this way, they believed, the Republican Party could establish a firm power base in the South.

Johnson's relocation policies failed and the Republican, Thaddeus Stevens, proposed a radical redistribution of land by confiscating the property of 70000 planters, who represented only 5 percent of the South's white population. The approximately 394000000 acres of land should be redistributed in 40 acre allotments. But the Radicals failed to gain the support of the moderate Republicans and even some of the Radicals.

On March 2, 1867 the Republicans passed an act outlining their general plan of reconstruction. Three subsequent acts provided machinery for implementing the programmes. Johnson vetoed all the measures but Congress passed them quickly and easily over his vetoes. Thus two years after the end of the war reconstruction began anew. It repudiated the pro-Johnson governments in ten of the southern states and divided them into five military districts. The military governments were given broad powers and the responsibility to launch new programmes of reconstruction. They were required to enroll qualified voters and organise elections for a state constitutional convention which had to draft new state constitutions providing for black suffrage. When a state had ratified the Fourteenth Amendment and Congress had approved the state's constitution, it would be entitled to representation in Congress. On June 13, 1866 Congress passed Amendment X1V which gave the ex-slaves citizenship and guaranteed all American citizens the "privileges" and "immunities" of citizens. The amendment was proclaimed on July 28, 1868. On February 2, 1869 Amendment XV was passed and proclaimed on March 30, 1870. It provided that their should be no discrimination in the granting of the vote on "account of race, color or previous condition of servitude". Each of the 11 states fell under the control of Radical Republicans, a control that was only achieved by the selective granting of the vote and manipulation of government.

The implementation of these policies was to a great extent in the hands of the restored local loyal governments who depended on the military to survive a rather hostile white majority. The ex-slaves showed limited enthusiasm for political activities. In 1869 the Freedmen's Bureaus were abolished. By 1867 the traditional Democratic leadership regained its position in local legislatures in 8 of the 11 states. Reconstruction policy was systematically ignored. Voting qualifications were the prerogative of the state governments and different measures were introduced to limit the number of blacks obtaining the vote. Blacks were either reluctant to challenge the white powers or afraid of the various anti-black vigilante groups that appeared all over the South. Blacks tended to withdraw from public political activity devoting their energy to finding ways and means to make a living. A strong reaction set in in the South with the development of the policy of segregation ("separate but equal"). Amendment XV was bypassed by state legislatures by introducing measures that made it very difficult for blacks to register as voters.

Why were federal troops not used to protect blacks and to prevent the sort of violence that was being organised against anybody, predominantly black but not exclusively so, who were regarded as disloyal to the South's traditional way of life? The fact is that the Northern Republicans, with their own forms of discrimination against blacks and their own restricted voting rights, lost interest in the cause of the blacks.

\section{Reconstruction policy in Germany}


The collapse of the Allied Control Council confirmed the fact that the four occupying powers were not pursuing a coherent policy. The Soviet Union interpreted denazification as giving them the right not only to uproot the military and political elite but to destroy the entire social structure in its zone and to replace it with one modeled on that of the Soviet Union. Planning started as early as 1944 when German communist emigres in Moscow were organised as political agents that could enter Germany with the Red Army. A social revolution was justified on the argument that Hitler's domination was due to the social structure of Germany and any purge that did not first and foremost aim at the destruction of capitalism was no purge. ${ }^{25}$ The Russians did not introduce a mechanical or bureaucratic process for identifying and removing nazis. They only distinguished between those who were well disposed toward communism and the Soviet Union and those who were not. Those ex-nazis who were willing to join the Communist Party of Germany (KPD) were accepted as friends no matter what their previous history was. ${ }^{26}$ Nationalisation of land, banks and industries was systematically introduced and control of all aspects of public life by the Communist Party in its new dress as the Social Unity Party (SED) was systematically enforced.

In the Western zones the Americans took the initiative. The concept of collective guilt played an important role in their approach to denazification. It meant that the entire German population was to be scrutinized and denazified. The Joint Chiefs of Staff Directive (JCS 1067) of April 1945 made the purging of Germany the main aim of denazification. The general mood in the United States of 1945 was that denazification could not be severe enough. ${ }^{27}$

JCS 1067 displayed a great distrust of the German people and no desire to cooperate with those Germans who were opponents of national-socialism. The Military Commander of the American zone, General George Patton, was instructed to dissolve the Nazi Party, its formations, affiliated associations, supervised organisations and all Nazi public institutions; to remove and exclude from public office and private enterprise all supporters of the Nazi regime; and to confiscate all property that belonged to Nazi organisations or leaders. ${ }^{28}$ All individuals whose names were listed in the so-called automatic arrest categories were to be interned pending their trial. This preliminary blacklist contained not only the names of all Nazi leaders and high officers but also the names of more than a thousand industrialists. ${ }^{29}$

The whole concept of a purge imposed from the outside was so unique and alien to American military staff that serious differences developed among them. Denazification was soon to develop into a whole plethora of directives and practices. In September 1945 the American war hero, Patton, who was not only regarded as too lenient to the Germans but also dared to critisise the aims of the policy, was relieved of his command by General Dwight Eisenhower. ${ }^{30}$

On Soviet denazification see Stefan Doernberg, Die Geburt eines Neuen Deutschland, 1945-1949 for the Communist point of view, and J P Nettl, The Eastern zone and Soviet Policy in Germany, 1945-1949 for a non-communist point of view. See also Gregory Sandford, From Hitler to Ulbricht: the Communist reconstruction of East Germany, 1945-1946 ( Princeton UP, 1983).

26 Justus Fürstenau, Entnazifisierung. p.23 (Herman Luchterhand Verlag, Berlin, 1969).

27 See Julian Bach, America's Germany (Random House, New York, 1946) as a representative example of this mood.

28 See John Gimbel, The American Occupation of Germany. Politics and the Military pp. 1-34 (Stanford UP, 1968).

29 Harold Zink, 'The American denazification program in Germany', Journal of central European Affairs, vol 6, no 3, October 1946, pp. 228-229.

Dwight Eisenhower, Crusade in Europe, pp, 224-225 (Doubleday, New York, 1950). 
The United States Military Government (USMG) was saddled with the impossible task of registering and categorising each individual citizen in their zone. A comprehensive questionnaire with 131 questions was drafted and 13 million distributed. By June 1, 1946 a total of 1613000 had been returned. ${ }^{31}$ General Lucius Clay acknowledged that even if 10000 Americans were assigned full time to the task of processing the questionnaires they could not succeed in purging the German people. ${ }^{32}$ The American military and the German people became disillusioned. Clay began to realise the dangers of estrangement and the creation of martyrs. To prevent this, he decided that denazification should become a German affair. ${ }^{33} \mathrm{He}$ forced the new German leaders to accept the Befreieungsgesetz of March 3, 1946 which embodied the new American policy. The German leaders, struggling to establish their authority, were made responsible for implementing a law which did not reflect their views. ${ }^{34}$ The German people were divided into five categories (Major Offenders, Offenders, Lesser Offenders, Followers and Exonerated - the latter soon to be called Persilscheine) and special German tribunals (Spruchkammern) were made responsible for prosecuting and punishing them. The pretence of German responsibility for the purge was soon revealed when the USMG introduced different amnesties, such as the Jugend Amnestie and the Weihnachsamnestie.

Denazification became a huge burden to the USMG and Washington was pressing for an end to the process. Although the American army was receptive to the desire to get denazification done with, they supported General Clay when he pointed out that it would have devastating moral and pshychological consequences if denazification was stopped abruptly. New pressure was exerted on the German tribunals and March 31, 1948 was set as a deadline for completing the process. In spite of genuine efforts to achieve this goal, there were still 540000 untried cases and 17000 people in internment when the deadline was reached. ${ }^{35}$

The fact that Britain had a Labour government in power led to significant differences between the American and British policies. In contrast to the Americans the British adopted a very conciliatory attitude to the leftists opponents of the Nazi regime and they tended to favour members of the Social Democratic Party (SPD). ${ }^{36}$ They did not hesitate to use Socialist leaders to purge Germany of Nazi leaders, and even some capitalists. They did not introduce a sweeping denazification programme because they did not regard it as a priority. Britain's own post-war economic weakness enabled her to be more appreciative of the economic problems facing Germany. She was more inclined to focus on economic problems and to use the opportunity to convert some of the German companies into mixed state-private enterprises, introducing a very limited social revolution, something anathema to the Americans. ${ }^{37}$ Britain did not introduce automatic arrests, lengthy questionnaires or compulsory registration, and they did not leave it to the accused to proof that they were not active nazis. They were slower in handing over aspects of the political administration to the Germans than the Americans because of their serious lack of

Justus Fürstenau, op. cit., p. 38.

John Gimbel, op. cit., p.141.

Lucius D Clay, Decision in Germany, pp. 67-70 (Heineman, London, 1950).

R Maier, Ein grundstein wird Gelegt. Die Jahre 1945-1947, p. 219 ( Rainer Wunderlich, Tübingen, 1964).

Justus Fürstenau, op. cit., pp. 91-92.

Raymond Ebsworth, Restoring Democracy in Germany. The British Contribution, pp. 31-35 (Stevens, London, 1960).

Robert Fritsch, 'Entnazifisierung. Die fast Vergessene Versuch einer politischen Säuberung nach 1945', Aus Politik und Zeitgeschichte, 10.6.1972, pp. 18-20. 
confidence in the Germans to manage their own affairs. Political parties were only allowed in September 1945 and the first elections for Landtage were only held in April 1947, almost six months later than in the American zone. There was no general denazification law in the British zone and each German Land followed its own thinking along the general guidelines laid down by the British Military Government.

Perhaps the most striking feature of the British policy was its efforts to re-educate the German people. This was specially aimed at the German civil servants and members of local government. The British forced the Germans to adopt a system of local government very different from the traditional German system and modeled more on that of Britain. The Americans consistently refused to intervene in the traditional system of local government. ${ }^{38}$ British efforts to force the Germans to accept their civil service system, however, failed. ${ }^{39}$ The Education Branch of the British Occupation was responsible for reorganising the educational system and for introducing British democratic ideas into German education. They succeeded in organising youth groups, establishing education centres and designing a scheme of sponsored visits to Great Britain to bring the German youth in contact with British democracy.

The ultimate aim of French policy was different from that of both the Americans and the British. For the French Hitler was the end product of a line of development that began with Bismarck. Nazism was associated with Prussianism. The totalitarian state was the necessary outcome of a unitary Germany. The French aim was to destroy German unity permanently. France was the only ally to remain a supporter of the original policy of dismemberment, and that was the main reason for the initial lack of French cooperation in the Allied Control Council. Dismemberment should lead to the creation of peaceful German states on the Rhine and the incorporation of parts of Germany into the French Republic. The permanent economic weakening of Germany and maximum reparations for France were two other important elements in French policy. To achieve the aim of reconciling Germans with the idea of possible French rule, it was essential to win the goodwill of the Germans. They must learn to appreciate the conciliatory French policy towards them. Denazification and purges played a minor role in French policy. They did not believe in scrutinizing the entire German population and concentrated on treating the Germans as individuals. ${ }^{40}$ They paid heed to the demand by German intellectuals that the Germans should be allowed a process of self-purgation (selbstreinigung). In each Kreis an Examinations Committee (Untersuchungsausschuss) was established with a Purging Committee (Saüberungsauschuss) at the top which made the final decisions and passed it on to the Military Government. The committees were made up entirely of Germans and concentrated on purging the public administration. Very little attention was given to the private sector. Membership of the National Socialist German Workers' Party (NSDAP) and its affiliated organizations was not regarded as prima facie evidence of guilt, but non-membership was accepted as proof of innocence. In each Land a Political Advisory Council and a Commissioner for Political Cleansing was appointed by the Council on the advice of the political parties. The Council decided on the sanctions to be applied to those classified as punishable.

Drastic land reform or nationalization of banks and industries were not important aspects of policy, although they did receive limited attention in the British and French zones. The Germans were also subjected to reparations payments. The Potsdam Agreement allowed

Raymond Ebsworth, op. cit., pp 78-99.

Ibid, pp. 140-158.

F Roy Willis, The French in Germany, 1945-1949, p. 150 (Stanford UP, 1962) 
Germany to revive the industries only to a level which would secure a standard of living equal to the average in Europe. Factories capable of being used for war purposes therefore had to be dismantled and their machinery removed. It had been agreed that the Russians should be the chief beneficiaries although no agreement was reached on the exact amount or volume of reparations payment they might receive. In the early months the Russians helped themselves from both Berlin and their zone by taking any machines they thought might be useful. In the Western zone dismantling was carried out under an international commission and was much slower and more methodical. Although dismantling went on for four years, the total amount of machinery removed from Germany was surprisingly small - perhaps 4 percent of their total industrial capacity. The whole purpose of economic policy was to get the economy going, and by the middle of 1946 the USMG was exhorting Germans to produce more to pay for imports. The need for a unified economic policy led to the formation of Bizonia by the Americans and the British. The French were reluctant to join, but developments in East Germany eventually left them no option. The Soviet Union regarded the formation of Bizonia as an unfriendly deed and it played an important role in the increasing Cold War tensions in Germany.

Once the Marshall Plan was launched and Germany was urged to join the Western bloc, dismantling became insupportable. What was the point of importing ball-bearings from the United States for the German railways while destroying German factories that could make them because they had once supplied Hitler's armies? German workers and leaders began to sabotage or delay dismantling in a variety of ways. As time went on the Germans made it a point of honour to replace all the old machines that had been removed with the latest British, American or Swiss equipment. In the long run it gave them a competitive edge over Great Britain with its outdated equipment.

Political reconstruction gave the occupation powers control over the granting of voting rights and the licensing of political parties. Parties associated with right wing extremism were regarded as the main threat, and the rebuilding of the Social Democrats and the old Christian parties were seen as the best option. The Americans, unlike the British and the French, preferred the latter and the moderate wing of the Social Democrats and were rather concerned about the Marxist wing's close liaison with the German Communist Party. The fact that the Soviet Union was an ally and one of the occupation powers, and that Joseph Stalin was no longer regarded by many in the West as the authoritarian ruler who send millions of Russians to their death in the thirties, left the door open for the Communist Party to compete with the Social Democrats for the allegiance of the workers. The German Communists, however, were inhibited by the German fear of the Russians and in particular by the behavior of Soviet soldiers during the invasion and in the Soviet zone. While the USMG kept an eye on the activities of the left parties, the leftist parties enjoyed more status and support in the French and British zones. The Catholic states in the American zone, with its agricultural and rural areas, presented less of a problem than the industrialised areas under British and French control. The strong reaction to denazification, the economic plight of the German population hovering on the brink of complete starvation, and the unilateral behaviour of the Soviet Union obliged the Americans to force the pace of political reconstruction. The decision at the London Conference in 1948 to create a West German state and to establish a Parliamentarische Rat to draft a new constitution, set off a race against time to get a pro-Western-style political system adopted and a pro-Western government in power. The federal constitution, or Basic Law as the Germans preferred to call it (a Grundgesetz not a Verfassung) was based on a mixture of the American congressional and federal system and the 
German tradition of a Chancellor with important powers and a parliament with real powers. ${ }^{41} \mathrm{~A}$ very complicated electoral system, which was a combination of proportional representation and personal representation of an electoral district, was introduced to prevent the rise of a plethora of small parties that could create the political chaos that was the weakness of the Weimar Republic.

A total reverse in the fate of and the future of Germany was made inevitable by the fact that Germany became the focal point of the new Cold War. Disarmament, demilitarisation and the idea of a neutral Germany lost their meaning in the face of the competition between the Soviet Union and the United States for the loyalty of the German people. The division of Germany into two separate states, the total collapse of any possibility of a peace agreement with Germany and the integration of the two Germany's into the sphere of influence of their occupying powers, revolutionised policy towards Germany. The erstwhile leper became the most important ally. Economic retribution was replaced by a spectacular programme for the economic revival of Germany, turning it into a showpiece of successful capitalism. Rearmament and the co-opting of Germany as a defence partner entirely reversed the position of Germany. The carefully crafted policies of its first chancellor, Konrad Adenauer, to integrate West Germany politically, economically and militarily into the American alliance, left the Social Democratic opposition under the leadership of Kurt Schumacher in the cold. The fate of Germany was completely turned around - at a price: the new issues would become German reunification, control of Berlin, the fiction of four power control and Germany's military and defence role. One thing remained unchanged: the moral baggage and defects that the German people had to carry. That was all that remained of the original intention to punish Germany so severely that she would never again become a force in Europe or in the world. The West used the controversial Nürnberg trials of the leaders of the Third Reich for war crimes, to stamp the atrocities of the war firmly on the German mind. A new concept in international law - crimes against humanity was born. ${ }^{42}$ This single aspect made the situation in Japan entirely different from that in Germany.

\section{Reconstruction policy in Japan}

The Potsdam Declaration on Japan of July 26, 1945 provided for a policy similar to that in Germany although less harsh words was used against Japan and the total condemnation of the German leaders and people were absent: "There must be eliminated for all times the authority and influence of those who have deceived and misled the people of Japan into embarking on world conquest, for we insist that a new order of peace, security, and justice will be impossible until irresponsible militarism is driven from the world." 43 There was also an emphasis on the role of ideology in perverting the Japanese nation. The first Post-surrender Policy of August 24, 1945 demanded that "persons who have been active exponents of militarism and militant nationalism will be removed and excluded from public office and from any other position of public or substantial private responsibility." The JCS directive of September 1945 defined the latter group as "influential members of any Japanese ultranationalistic, terroristic, or secret patriotic society, agencies or affiliates... or who manifest hostility to the objectives of military occupation."

\footnotetext{
$41 \quad$ Arnold Heidenheimer, The Governments of Germany (Thomas Y Crowell, New York, 1971).

42 German Views of the War Trials. (Southern Methodist UP, Dallas, 1955); Telford Taylor, The Anatomy of the Nuremberg Trials (Bloomsbury, London, 1993).

43 Supreme Commander for the Allied Powers, Government Section, Political orientation of Japan: September 1945 - September 1948. (USGP, Washington, 1949).
} 
In spite of the same principles and aims, the occupation policy in Japan differed markedly from that in Germany. Two factors shaped these differences. Firstly the absence of any important joint allied control of the situation in Japan. Although Great Britain, China and Russia baulked at the nominal role given to them in the occupation of Japan, there was no way in which they could pressure Washington to grant them more than an advisory function. The absence of four-power control and the complete dominance of American policy by one man, Douglas MacArthur, ensured some form of consistency and avoided much of the chaos that was so typical of policy in Germany. Secondly the bombing of Hiroshima and Nagasaki and the destruction of lives and property weighed against the Americans claiming the same moral high ground that they did in Germany.

This is already evident from the way in which the Tokyo War Trials were conducted and the special position accorded to the Emperor. The Emperor was not accused of any crimes or participation in the war. The decision not to abolish the emperorship in favour of an elected president was based on the advice of former ambassador Joseph Grewe, who persuaded Washington that the Emperor was a vital factor in controlling and stabilising the situation in Japan. The accused in the Tokyo trials were not indicted for offences against the civilian population. They were accused of crimes against peace and of conspiracy to conduct a war of aggression. No political or military organisation similar to that at Nürnberg was indicted. ${ }^{44}$ While the Nürnberg trial papers were immediately published in 42 volumes, the Tokyo verdict was only published in 1977 and not in an official version. ${ }^{45}$

Ideological cleansing was conducted in a different way. There was no effort to classify the population according to political sympathies or affiliations. There were no public trials of selected groups and individuals and no general questionnaire to be completed. A selected group of leaders had to complete a brief questionnaire of 23 questions. The purges were conducted by a national council, 46 regional councils, 118 municipal councils and a staff of 1000 officials. While 3623112 individual cases (21,7\% of the population) were investigated in the American zone of Germany alone, the total for the entire Japan was 2308863 (or 3,2\% of the population). Only 29\% (or 210000 ) Japanese were eventually purged against 2,5\% in the American zone of Germany alone. Military officers formed $80 \%$ of the Japanese purged. ${ }^{46}$

The new democratic constitution was forced through by MacArthur and was generally referred to as MacArthur's constitution. There was very little effort to harmonise the constitution with Japanese political traditions. Although the office of the emperor was maintained, he was stripped of all political power and influence, something completely unacceptable to a large majority of the Japanese people. ${ }^{47}$ The feudal system was abolished and with it the nobility and the use of aristocratic titles. Article nine of the constitution placed a permanent ban on the existence of a Japanese army, except for a small army of 70000 for preserving internal order. Japan was forbidden to ever again conduct war. Women were granted the suffrage and political parties based on mass support were introduced. The executive and legislative branches (including an elaborate American committee system) were given precisely defined and enhanced powers. An independent judiciary and a Bill of Rights were intended as a safeguard against any

$44 \quad$ Richard H Minear, Victor's justice. The Tokyo War Crimes Trial (Princeton UP, 1975).

45 B V A Rolling, The Tokyo Trial and Beyond: reflections of a peace-monger (Polity, Cambridge, 1994).

46 Hans H Baerwald, The Purge of Japanese Leaders Under the Occupation (University of California Press, Berkeley, 1959), p. 80.

47 Jun Eto, A Nation Reborn (International Society for Educational Information, Tokyo, 1974). 
attempt to usurp power. A very elaborate system for amending the constitution was to ensure that guarantees were put in place to discourage efforts to change the constitution once occupation came to an end. A two-thirds majority of both houses of the Diet and a simple majority in a referendum were required. ${ }^{48}$ The most drastic measure of all was the abolition of the Shinto religion as the official state religion. ${ }^{49}$

Land reform was an important aim of reconstruction policy. It was a potentially very sensitive issue with accusations about America practising socialism or introducing a policy that could be associated with the drastic land nationalisation in the Soviet zone of Germany. Tenant farmers were to be replaced by freeholders. The Land Commission of 1946 received representations from owners, tenants and landlords. The Commision selected land for purchase and resale to eligible tenant purchasers who were given government bonds to pay for the land. The policy was skillfully managed and continued by the post-war Japanese governments. Eventually 1137000 hectares of riceland and 796000 hectares of farm land were alienated from the landlords and sold to 4778000 freeholders. This created a new class of conservative landholders. ${ }^{50}$

The least successful part of reconstruction was the plans to break up the 1200 monopolies in industries controlled by the zaibatsu. The zaibatsu was an industrial-financial monopoly controlled by a few aristocratic families. The Mitsibushi family, for example, controlled 356 large companies. Ten zaibatsu families were in command of three quarters of Japan's commercial and financial enterprises. ${ }^{51}$ The Americans were faced with a serious dilemma: how do you restructure and redistribute such a concentrated economy without being accused of introducing socialism? The American aim was to redistribute the productive units of the economy to as many people as possible by creating a large number of small businesses and medium size enterprises. In this way a new and prosperous middle class could be created. The Americans used their anti-trust laws to unbundle the conglomerates and to force them to decentralise and sell off a large number of the companies under their control. Only 28 conglomerates were successfully broken up. ${ }^{52}$ The demand that the Japanese economy, like that of West Germany, be rebuild not only to prevent the threat of communism, but to act as a showpiece of the American system in the Far East, was precisely the reason that the Americans completely reversed their restructuring of the economy after $19488^{53}$ Ironically enough the remaining conglomerates played a vital role in the economic recovery of Japan after 1955 and especially in the seventies. ${ }^{54}$

The Americans encouraged the establishing of trade unions whose membership increased sharply. They were intended to be a counterweight to the old elite and ambitious politicians. The great interest that left wing Japanese socialists and communists showed in the trade unions

\footnotetext{
48 Theodore McNelly, 'The Japanese Constitution: Child of the Cold War', Political Science Quarterly 7/2, June 1959, pp. 176-195.

William K. Bunce, Religions in Japan: Buddhism, Shinto, Christianity (Charles Tuttle, Rutland Vt, 1955).

Ronald P. Dore, Land Reform in Japan (Oxford UP, 1959); Al McCoy, 'Land Reform as CounterRevolution: US Foreign Policy and the Tenant Farmers of Asia', Bulletin of Concerned Asian Scholars 3/1, Winter Spring 1971, pp. 17-19.

51 Thomas A Bisson, Zaibatsu dissolution in Japan (University of California Press, Berkeley, 1954).

52 Theodore Cohen, Remaking Japan: The American Occupation as New Deal (Edited by Herbert Passin. Free Press, New York, 1987).

53 Jerome Cohen, Japan's Postwar Economy (Indiana UP, Bloomington, 1958).

54 Dennis B Smith, Japan since 1945: the rise of an economic superpower (Macmillan, Basingstoke, 1995).
} 
scared the USMG. Instead of being a progressive democratic force, the unions formented labour unrest and engaged in massive strikes, something irreconcilable with the ideal of rebuilding the Japanese economy. ${ }^{55}$ These developments, together with the Communist takeover in China in October 1949 and the outbreak of the Korean War in June 1950, forced the Americans hastily to sign a peace treaty with Japan on September 8, 1951. The peace treaty that not only eluded them in Germany, but also was the cause of great Cold War tensions in Europe, was forced through by America against the will of its Asian allies in the Far East. The latter was shocked by the sudden change in American policy and found the new special status of Japan and cooperation with Japan difficult to digest. ${ }^{56}$

\section{Reconstruction policy in the Boer Republics}

While the signing of a peace treaty was the by-product of reconstruction in Japan and the victim of reconstruction in Germany, the Peace Treaty of Vereeniging (May 31, 1902) was an important and controversial part of reconstruction in the Boer Republics. It had a marked influence on Milner's reconstruction policy. Milner was critical of prior commitments that could restrict his freedom to achieve his aims. The commitment to the restoration of self-government (article 7) was a matter of special concern to him. Self-government should only be considered once his aims of total British demographic and economic control were well established.

Prosecution of defeated leaders and the burgher forces - with the exception of colonial rebels - played an even lesser part in South Africa than in the American South. The Boer negotiators at Vereeniging were in favour of a blanket amnesty that should include colonial rebels. Article 4 of the treaty, however, guaranteed only republican burghers immunity from civil or criminal proceedings and article 3 gave the assurance that their personal liberties and property would not be endangered. Cape and Natal rebels were subject to prosecution for high treason and automatic suspension of their voting rights for an indefinite period. Special military courts were created for their trials and by 1901 a total of 33 Cape rebels had already been executed. ${ }^{57}$

On August 2, 1902 a Royal Commission was appointed to investigate the administration of martial law. A total of 794 complaints were brought to the Commissions attention. The Commission recommended suspension of the death penalty and imposed much lighter sentences in 300 of the cases. Death sentences were commuted to imprisonment for periods from two to three years. This change in the British attitude was caused by the same moral factors that played a role in Japan, a feeling of guilt and responsibility for the way in which the British conducted the war: the concentration camps with their abnormally high death rates; and the scorched earth policy. By August 1902, however, there were still 700 Cape rebels serving sentences. In July 1903 John X Merriman proposed in the Cape Legislative Assembly that a general amnesty be granted, but Jameson and his Progressive Party resisted all efforts for amnesty. General amnesty was only granted as late as 1906 . The Cape government, however, ensured its own immunity

\footnotetext{
55 Joe Moore, Japanese Workers and the Struggle for Power, 1945-1947 (University of Wisconsin Press, Madison, 1983).

$56 \quad$ Michael Yoshitsu, Japan and the San Francisco Peace Settlement (Columbia UP, New York, 1983).

$57 \quad$ C J Scheepers Strydom, Kaapland en die Tweede Vryheidsoorlog (Cape Town, 1943), p. 139; See also J H Snyman, 'Rebelle-verhoor in Kaapland gedurende die Tweede Vryheidsoorlog met spesiale verwysing na die militêre howe, 1899-1902', (Archives Year Book for South African History, 25, 1962).
} 
against claims and prosecutions as early as 1901 with the passing of an act that exempted all colonial officials involved in the administration of martial law from claims and prosecutions.

Cape citizens could submit claims against the British military administration, mostly for providing horses and forage and food supplies. Approximately 17000 claims were filed and by 1909 altogether $£ 2$ million was paid out. The suspension of the voting rights of Cape rebels had an impact on the election of $1904{ }^{58}$ The Progressive Party of Jameson won the election but when the rebels' vote was restored it was defeated in the election of 1908 , when the South African Party and the Afrikanerbond regained their positions.

Repatriation and resettlement were Milner's first priority. The country was totally devastated and farming and commercial activities at a stand still. Milner himself was shocked by the extent of the damage done by the war and the scorched earth policy. ${ }^{59}$ Under these circumstances the logistics of repatriation and resettlement was daunting. Approximately 31000 Boer prisoners of war, of whom the majority were in overseas camps, 116000 white and 115 000 black inmates of concentration camps, 500 Uitlanders, 21000 Bittereinders and 5400 National Scouts, together with a large number of blacks and coloureds who served with the British army, had to be transported to their homes where in the case of the majority of the Boers, nothing was left of the house or the farming equipment and the stock. The republicans regarded the $£ 3$ million for "assisting the restoration of the people to their homes and supplying those who, owing to war losses, are unable to provide for themselves..." (Article 10 of the peace treaty) as reparations. Milner used it to resettle loyalists like Uitlanders, National Scouts and Hensoppers. Milner gave priority to the returning "uitlanders" and to Hensoppers and National Scouts that left a bitter taste with the Bittereinders and the returning inmates of concentration camps. $^{60}$

War debt and compensation thus differed from that in the other three cases. In his early views on reconstruction Milner was still thinking in terms of the defeated republics paying a small amount as indemnity to the British government. In the end it turned out to be the British government paying war debts and reparations money. The British denied that these payments were reparations, and tried to defend it as a free grant (see article 10 of the peace treaty) or as reconstruction "loans". A bitter dispute developed about the amounts to be paid out, the way in which claims had to be submitted and the clumsy and unsympathetic way in which these funds were administered. The loss of their independence, the way in which Great Britain conducted the war and the economic plight of republicans after the war, became important factors in consolidating a new political consciousness among Afrikaners. The failure to provide adequate compensation and the serious maladministration of the limited funds alienated Hensoppers, National Scouts and even Uitlanders. They were driven together in there opposition to Milner. It contributed in a small way to the improvement of relations between them and the Bittereinders.

Milner was convinced that a military occupation was the last thing that should be considered in South Africa. He wanted to convince the Afrikaners that they would be better of under his administration than under the republican governments. He did not expect serious resistance from the Afrikaners: "once beaten and then fairly treated, and not to much worried on

R. Davenport, The Afrikaner Bond. The History of a South African Political Party (Oxford UP, Cape Town, 1966), pp. 247-249 and 263.

C Headlam, The Milner Papers 11 (London, 1933), p. 364

A P J van Rensburg, op. cit, pp 230-242. 
his own 'plaats' in his own conservative habits I think he will be peaceful enough". ${ }^{61}$ But immediately after the signing of the peace treaty security became Milner's main worry. He was preoccupied with the need to obtain Whitehall's approval for the maintenance of a substantial British garrison in South Africa. Before he left South Africa in 1905, the British military force was reduced from 200000 to 20 000. The special South African Constabulary which was raised for a dual purpose - to protect the peace and to provide a reservoir from which British immigrants could be drawn - was reduced from 10000 to 6000 by November 1902 and by a further 1000 per year for the next four years. It was finally disbanded on June 30, 1908. In republican minds there were no doubts that this was not a police force but an occupation force. ${ }^{62}$

Resettlement of dislocated people and the settlement of large numbers of immigrants involved land issues. The Burgher Land Settlement Scheme, Milner's effort to solve the problem of landless poor white farmers who struggled to make a living as bywoners by making them "sharecroppers of the state", was a complete failure. ${ }^{63}$ The large-scale settlement of British immigrants to reverse the demographic situation in the Transvaal and the Free State also failed. When he left, only 557 British immigrants had settled in the Transvaal and 691 in the Free State. ${ }^{64}$ Adverse weather conditions, the serious drought of 1905-06, difficult farming conditions and improper administration of the schemes all contributed to the disillusionment of many settlers. To the Afrikaners the land settlement schemes looked uncomfortably like a concerted plot to drive them of the land. The scheme stimulated anti-British and anti-imperial sentiments.

Black Africans in particular were even more disillusioned with the land policy. Some who settled on abandoned white farms during the war, refused to leave. ${ }^{65}$ Demands for land were regularly put before the government and were eventually referred to the South African Native Affairs Commission (the Lagden Commission 1903-1905) that acknowledged the land hunger needs of black Africans and recommended that serious attention be given to land policy. ${ }^{66}$

Black African demands for land was a hot political issue as black and coloured African leaders utilised the war and reconstruction to promote political rights and demands among their people. Black and coloured leaders were under the impression that they would be rewarded for their support of the Empire in the war. They hoped for more land, extension of the Cape political rights to the new colonies and the granting of full and equal rights. They were bitterly disappointed by the peace treaty that postponed any decision on political rights until after the introduction of self-government (article 8). It soon became obvious to them that their demands were a low priority compared to the British desire for reconciliation with the republicans. Black political organisations were established in different parts of the country. In 1903, for example, the Transvaal Vigilance Association and a branch of the Cape-based South African Native Congress were founded, in the Transvaal. In the Free State the Bloemfontein Vigilance Committee was founded, followed by the Orange River Colony Native Vigilance Association in

C Headlam, op. cit, pp. 35-36 (Milner to Fitzpatrick, 28 November 1899).

A P J van Rensburg, op. cit, pp. 193-195.

S Marks and S Trapido, 'Lord Milner and the South African State' in P. Bonner (ed.), Working papers in southern African Studies, vol 2 (1981), p. 76).

A P J Van Rensburg, op. cit., p. 227.

S Trapido, 'Landlord and tenant in a colonial economy: The Transvaal, 1880-1910', Journal of Southern African Studies 1 October 1978, p. 45.

C J P le Roux, 'Die Verhouding tussen Blank en Nie-blank in die Oranjerivierkolonie, 1900-1910' (Archives Year Book for South African History, 1987/1), pp. 65-68.
} 
$1904 .^{67}$ In the same year the coloured leaders founded the African Political (later People's) Organization under the leadership of Dr. Abdullah Abdurahman. Their aim was to improve coloured education and participation in colonial government and to agitate for the extension of the franchise to the new colonies. The new political awakening eventually led to the South African Native Convention in March 1909 and the founding of the South African Native National Congress (which later became the ANC) in January 1912. African nationalism thus had its small beginning as a direct result of the reconstruction era.

Afrikaner nationalism based on two pillars - a political reorganisation and a cultural movement - was the most important direct result of the reconstruction policies. Milner's policy of reconciliation and anglicisation not only achieved the direct opposite of what he intended it to do, but also represented a serious contradiction. The more his anglicisation policy developed, the stronger the resistance to reconciliation grew. The Boer war leaders became political leaders and were foremost in their criticism of and reluctance to cooperate with Milner. Louis Botha, for example, refused to accept an appointment on the Executive Council in the Transvaal and Christiaan de Wet refused to accept compensation money. The anti-Milner feeling was running high by 1905, and with the growing influence of the opposition Liberal Party in the British Parliament, which supported early self-government for the two republics, Milner, realised that self-government could not be postponed long enough to enable him to strengthen pro-British sentiments in South Africa. The reaction to Milner's policy was only one of a number of factors that eventually led to the establishment of two Afrikaner political parties - Het Volk in the Transvaal in January 1905 and Orangia Unie in the Free State in May 1906. The granting of self-government to the Transvaal in December 1906 and to the Free sate in June 1907 opened the way for the two defeated people's to take political command of their futures. Het Volk won the election of February 1907 in the Transvaal and Louis Botha became Prime Minister. In the Free State Orangia Unie won a convincing victory in November 1907 and Abraham Fischer became Premier.

The revival of Afrikaner political influence in the former republics was strengthened by the cultural awakening, which had a strong base in the Cape colony. The language movement in the Cape was stimulated by the war and sympathy with the republicans grew even stronger during the Milner reconstruction. Milner's efforts to use education and language policy to denationalise the Afrikaners backfired. A new language movement and a new education system (private schools for Christian National Education) gained in popularity and received encouragement from the new governments in the Transvaal and the Free State. Reconciliation was achieved in a completely different manner from that which Milner envisaged: reconciliation between Bittereinders, Hensoppers and National Scouts gradually grew, mainly through the efforts of Afrikaans church leaders and the disappointment with Milner's policies.

While his efforts to weaken Afrikaner nationalism failed and he had no understanding of the embryonic African nationalism, Milner's policy did pave the way for the eventual unification of the four colonies. The only long term positive result of Milner's reconstruction policy was the way in which it brought home to the four colonies the need for closer cooperation in economic policy and in race relations. His railway policy demonstrated the positive results for growth and development of constructive measures to secure cooperation. Milner's successful administration of the four separate and competing railway systems illustrated the possibilities of closer 
economic ties and the importance of viewing South Africa as an economic unit - the same factor that played a determining role in the American South, Germany and Japan. Labour unrest and the emergence of black and coloured African political aspirations, presented a common threat to white dominance and the economic and political stability of the sub-continent. Larger problems and external factors, similar to those in the other three cases, emerged to terminate reconstruction and to underline the need for a return to normality. The price for normality in South Africa and the American South was the same: protecting white rights.

Milner's concept of reconciliation did gain a hold in South Africa, but not in the way he wanted. Reconciliation through the development of a common South Africanism (and in the long run the restoration of republicanism) rather than a common acceptance of dominion status became a mainstream force in the development of South African history.

\section{Reactions to reconstruction}

The reconstruction policies in all four cases achieved only limited success. In not one of the four cases are the reconstruction period seen as a real and positive transformation of society. Although reconstruction did have a positive impact on a number of important aspects of the societies, these are overshadowed by the negative experiences and frustrations of the subject peoples.

The positive outcomes can be briefly summarised as follows:

- In the American South the restoration of the Union and the emancipation of the slaves.

- In Germany and Japan the democratisation of the two states and the restructuring of their political system.

- In South Africa the way in which reconstruction focused attention on the need for and the possibilities of unification.

The transformation of the four societies into something fundamentally different from what they were was not the result of reconstruction policies but of introspective reorientation and a self-analysis that was not aimed at achieving a radical transformation but a constructive reconciliation of the need for change and the necessity for self-assertion and self-respect. The American South retained an identity and personality of its own. Industrialisation and economic modernisation became the two most important forces to determine the end of reconstruction and a return to normality, but it left the Afro-Americans on the sideline where black aspirations gradually developed into a new social force that erupted eighty years later. The Germans accepted their guilt, acknowledged their responsibility for what happened and emphasised the need for coming to terms with their past and reinventing themselves through selbstreinigung. The Japanese accepted responsibility for the fact that authoritarian government and undue military influence led to fundamentally wrong policies. They were, however, themselves victims of one of the worst forms of violence - the only two instances in history in which the destructive atomic bomb has been used. In their process of self-analysis and self-orientation the Meiji ideal of modernisation was restored, releasing powerful creative and productive energy. Both Germany and Japan were in the fortunate position that an external factor - the Cold War determined their future, not reconstruction. They both had a basic democratic sense that could be 
cultured and they both had a tradition of discipline, strong creative minds and an ability to focus on what they were doing and to work extremely hard.

In South Africa reconstruction failed to understand and successfully address the two main forces that would shape South African history: Afrikaner and black African nationalism. The rise of the two nationalisms was only possible under the conditions created by the war and reconstruction. In this sense reconstruction shaped the future of South African history. Protecting white power and control was seen as the way in which some form of "normalcy" could be restored in a united South Africa.

\section{The role of the military in reconstruction}

In the case of East Germany the military was the main instrument in guiding a revolution from above. The fact that the collapse of communism in East Germany was sealed when Michail Gorbachev announced that the Brezhnev Doctrine, providing military support to the East German regime, would no longer apply, illustrates the nature of the military's inability to sustain the revolution. In the case of West Germany and Japan the military played a vital role in the final outcome of reconstruction but in a completely different way than what was originally intended. It was the military and economic necessity of rebuilding strong and loyal states in West Germany and Japan that led to a complete reversal of reconstruction policy. In the American South it was only a return to military government that made the failed Radical Reconstruction policy possible. It was only in South Africa that the military role could be described as insignificant although Milner used them as a backup to his new position of power.

Reconstruction proved to be a fragile means for the transformation of a society. Reconstruction by agency of the military ruled out fundamental changes, limiting the changes to particular circumstances and shortened time frames. In a society with even a restricted democratic tradition, it is very difficult for the military to win the hearts and minds of people. Domestic interests and local attitudes and identities have a way of reestablishing themselves even under the most difficult circumstances. Economic, social, personal and cultural factors are more important in determining the outcome of reconstruction and transformation policies than any grand design even if backed by strong military presence. It would be interesting to compare these four case studies, with examples from the Third World. 